\title{
Green Insights of Textile Industry in Bangladesh: A Case Study on Mozart Knitting Ltd.
}

\author{
Mst. Afroja Aktar
}

Lecturer, School of Business, Primeasia University, Dhaka, BANGLADESH

\begin{abstract}
The effectiveness of individual units of an Effluent Treatment Plant (ETP) agrees on the entire performance of the plant and the ultimately echoing effluent standard. In this study, an ETP of a composite textile industry in Bangladesh was investigated using this method. After completion of the stipulated study, findings came into force illustrated that water samples had been collected from the dyeing unit and accordingly had been used for the ETP and also been determined for the key parameters. The results were used to identify problems with the treatment units and broadly suggested for modifications. Simple but fully-bodied methodology was developed for assessing the performance of various treatment units and the ETP as a whole that could be implemented by ETP managers on a regular basis for improving the performance so that the effluent meets national standard as well as conforms to the requirements of international standard which is a compliance of the international buyers. To comply with the BB Guidelines commercial banks have taken initiatives on financing to the textile dyeing units in question with the implementation of ETP. The ETP's performance on Mozart Knitting Ltd. shown that it has been performing with the underprivileged management, especially chemical dosing were affecting the ETP's performance and that simple measures could address the problems. A number of equipment i.e middle pathways rolling, water transferring pipes should repair without more ado.
\end{abstract}

Keywords: Effluent Treatment Plant (ETP), monitoring, treatment, effectiveness, Bangladesh Bank (BB) guidelines, Commercial Banks performance, Ready-Made Garments (RMG)

JEL Classification Code: L67, K32

\section{INTRODUCTION}

Textile dyeing industries require huge water, which they pump out repeatedly from the ground or natural water sources resulting in depletion of ground water level. In the dyeing process textile industries generate the huge toxic effluent containing colors, 
sodium sulphate, sodium chloride, sodium hydroxide and traces of other salts. These are also generating 'after dyeing' and 'after washing' of garments or fabrics. After dyeing the wastewater produced is called 'Dye Bath Water' and after washing the wastewater generated is called 'Wash Water'. Dye bath water contains higher solids in the range 4-5\% whereas wash water contains only $0.5-1 \%$.

Based on the above mentioned facts, a technology is essential which can process such harmful toxic effluent water and transform it into reusable water. Thus, the textile industries will get the advantage of using the same water in the dying process repeatedly; also the salt used for dyeing can be reused or sold in the market. The technologies offered to overcome all problems pertaining to environmental pollution in respect to textile dying industries. The thrust of the technology is to convert entire quantity of effluent to zero level by separating water and salt using evaporation and separation technology.

Textile industries produce wastewater, widely known as effluent, as a bi-product of their production. The effluent contains several pollutants, which are essential to remove with the help of an effluent treatment plant (ETP). The "clean" water should then be safely discharged into the environment. Effluent from textile dyeing industries must meet the national effluent discharge quality standards set by the Government of Bangladesh, including the "Quality Standards for Classified Industries" (Tables 1), and may also need to meet additional standards set by international textile buyers. Consequently any ETP must be designed and operated in such a way that it treats the wastewater to these standards.

Up to June 2014, the data shows, Bangladesh Garment Manufacturers and Exporters Association (BGMEA) website that more than 5000 apparel manufacturing units have been registered with them (BGMEA \& BKMEA, 2013). Bangladesh Knitwear Manufacturers \& Exporter Association (BKMEA) has been marinating 1906 knitwear manufacturing units (BGMEA \& BKMEA, 2013). The RMG has become one of the largest manufacturing sectors in Bangladesh. The growth in this sector and other small and medium scale enterprises undoubtedly has a positive effect on national economic development, although there are also have some negative implications.

In particular, the large volume of water consumed and the water pollution generated through the dyeing process can have a severe impact on the local environment. Khan et al. reported that a semi-automated composite textile industry of 10-tone capacity produces $1250 \mathrm{~m} 3$ of effluent each day, which contains an assortment of chemicals including salts, dyes and bleaches.

The rapid but unplanned growth of industrial clusters, with several plants discharging large amounts of untreated or poorly treated wastewater, has led to confined to small area water pollution. As a result, water bodies and agricultural land are displaying reduced productivity and the biological diversity of these ecosystems is threatened. The result is not only environmental degradation, but also a reduction in the nutrition and income of families that traditionally depended on these resources, and they are not always the same people who get benefit from the job creations. One solution is to ensure that all the effluent needs to properly indulgence before it is discharged. The Bangladesh Environment Conservation Act (1995) and Rules (1997) make provision for this, categorizing factories according to their ability to pollute and to state the measures that must be taken to address this, including treatment. Under the 1997 Rules fabric dyeing and chemical processing industries are categorized as "Red industries," which is the highest category in the rules and for which an effluent treatment plant (ETP) is mandatory. 
Bangladesh Bank is the first central bank in the world that has very clear vision to promote green banking to safeguard the environment from unusual weather patterns, rising greenhouse gas, declining air quality, and BB has rightly issued a number of guidelines for Green Banking. BB has proactively come forward to complement by putting in place a fund of taka 2.0 billion to refinance lending for renewable energy generation and other environmentally beneficial projects like ETPs, energy efficient kilns for brick fields and so forth. As of December 2012, BDT 853.54 million out of BDT 2.0 billion revolving fund has been allocated by BB to the different green categories (Annual Report, BB; 2012 ).

Under these Rules, industrial units must treat as well as monitor the quality of their wastewater and stay within national discharge quality standards. [Table: 1]

Table 1: Discharge quality standards for classified industries composite textile plants

\begin{tabular}{ll}
\hline Parameter & Limit $\{$ Milligram(mg)/l $\}$ \\
\hline $\mathrm{pH}$ & $6.5-9$ \\
Total Suspended Solid (TSS), (mg/l) & 100 \\
BOD520 C, (mg/l) & $50 / 150^{*}$ \\
COD (mg/l) & $200^{* *}$ \\
Oil and Grease, (mg/l) & 10 \\
Total Dissolved Solid (TDS), (mg/l) & 2100 \\
Waste Water Flow & $100 \mathrm{~L} / \mathrm{Kg}$ of fabric processing \\
\hline Parameters based on classification of dyes used \\
\hline Total Chromium (as Cr molecule), (mg/l) & 2 \\
Sulfide (as S molecule), (mg/l) & 2 \\
Phenolic compounds as C6H5OH, (mg/l) & 5 \\
\hline *BOD limit of 150 mg/l implies only with physicochemical processing \\
${ }^{* * N o ~ o f f i c i a l ~ s t a n d a r d ~ f o r ~ C O D ~ o f ~ t e x t i l e ~ e f f l u e n t ~ b u t ~ t h e ~ g e n e r a l ~ s t a n d a r d ~ f o r ~ d i s c h a r g e ~ t o ~ i n l a n d ~ s u r f a c e ~ w a t e r ~ i s ~} 200 \mathrm{mg} / \mathrm{l}$.
\end{tabular}

Despite these laws, factories often show a reluctance to invest money in proper treatment because they consider it to be a non-productive use of money in an industry that is still emerging and striving to remain profitable in the highly competitive global market. Even where industries already have ETPs, and there is often the unwillingness to operate the plant correctly because of the high-running costs or the lack of experience to do so effectively.

As we gain knowledge more and more about the ecological problems our planet is facing, it becomes increasingly important to find ways to conserve our natural resources. When we recycle, use fewer petroleum products and household chemicals, and purchase environmentally friendly products, we are making an investment in our planet's future. Another way to have a positive impact on the environment is to learn how to save water. The project is said to be a green project when it is eco-friendly, self-sustaining and living in harmony with the earth. However, as the judgment of the training program of 'Green Banking' we visited the project of Mozart Knit Ltd. This study encompasses the green insides of the project along with repercussion of other industrial units in Bangladesh, which will be deemed as well as sustainable a 'Green' factory or industrial unit. 


\section{Project Approach}

In order to address the issues of increasing water pollution from textile industries and inadequate treatment, the project "Mozart Knitting Ltd.' which is managing pollution from apparel manufacturing industries in Bangladesh" was initiated. It is a vertically integrated knit composite unit with circular knitting, dyeing and garments. Total 19,297 sq land areas and 16,187 sq built areas with road access from two sides (north and south) at bashed, Ashulia, Dhaka. The company was setup this project in 2009.

For considering a case study on Green Banking activities, BIBM conducted a visit program as a part of Green Banking Training Schedule, where a number of different bank officials visited the titled industrial units. The aim of the unit's project was to reduce pollution while maintaining the profitability of the industries and thereby ensuring the income of the employees as well as the livelihoods of those who depended on the natural resources that were being impacted. The activities, therefore, involved cleaner production and improved wastewater treatment. The project was implemented by the owner from his own sources along with the owner initiatives working capital financed by Islami Bank Bangladesh Ltd. (IBBL), Ramna branch. The Project Size of BDT 100.00 crore whereas IBBL finance under its Islamic investment mode of i) IBB (HP) BDT 32.00 crore (HP- Hire Purchase usually finance for purchasing capital machinery), \& ii) MPI (BDT 50.00 crore (MPIMurabaha Post Import Finance usually used to non funded investment facilities for creating liabilities against settlement of imported goods under the structure of Letters of Credit (L/C).

In this component of the project, the team worked with a composite textile industry that had introduced an ETP from 2010 without having much experience in operating it. The purpose of the work was three-fold:

- To assist in diagnosing any problem with the ETP and to advise the factory team in the optimal management.

- To initiate a simple but effective system for regularly checking the function of the major components of the ETP in the unit and to evaluate the overall performance of the system; and

- To use this to create a generic set of guidelines for other textile factories to develop their own monitoring procedures.

The data collected from the factory could be used to make the process more efficient and cost effective. Whilst drawing another attention in mind that it will help us for providing evidences with the theory of environmental science. For installation of ETP in Bangladesh, the Department of Environment has set out specific rules for adaptation with environmental laws \& regulations. They are complying with their corporate environmental responsible standard to international buyers.

\section{THEORY AND METHOdOLOGY}

It is a descriptive study, covering green insights of textile dyeing industries in Bangladesh. The study rooted in primary, secondary and published sources. Visiting of the stipulated industrial unit facilitates to accumulate data \& implemented project abstract demonstrates how to put together data for using this study. Secondary \& Tertiary sources are the local laws. Published sources including the publications of Bangladesh Government \& Bangladesh Bank regarding ETP projects \& formulation of green banking policies, lends a hand for writing this study method. Global climate changes policy, which is formulated by United Nation \& collaborations with Ministry of Environment \& Forest in Bangladesh, fulfills up the study approach. The achievement of any research studies on economic analysis ultimately depends on the ease of 
use of the appropriate data. It is, therefore, essential that I payout sometimes discussing of the source and inadequacy of the data that may come to pass in pragmatic analysis. The difficulty stretches out in the ease of uses of the data. Missing assessment is a great dilemma in some data. So, the researchers should always keep in mind that the results of research work must be accomplished based on the quality of the data which must be accurate and fulfilled.

In Bangladesh few factories has been established ETP. There is no single, ideal ETP for a textile dyeing industry but the best options consist of several units. The combination of these units will vary depending on the exact type and function of the processing plant, which is determined to a large degree by the nature of the effluent. Typically an ETP for a textile industry would consist of primary, secondary and tertiary treatment (Lash and Kominek, 1980) to ensure the best performance; however, in countries where resources are limited, and factories must minimize their outgoings, they are less likely to adopt advanced treatment methods.

In Bangladesh, for example, electro-dialysis and reverse osmosis have only recently been introduced for wastewater treatment and the uptake is still limited. Consequently, the combination of the industrial units in an ETP in Bangladesh can vary considerably depend on the size of the factory, the exact nature of the industrial process and thus of the waste being generated. Sometimes the funds are available to operate the ETP, the compliance criterion specified by buyers and the engineering consultants contracted to design and construct the ETP. It makes more difficult to create a generic model for monitoring but guidance can be given based on the type of units and the performance standards typically expected for those units.

A combination of physicochemical and biological units are most commonly used in textile dyeing industries in Bangladesh (Ali etal, 2005), although pure physicochemical plants have also been observed by the project team. Depending on the combination of physicochemical and biological units selected the removal efficiency of the constituents differs: the ranges of percentage removal rates are to be given in Table 2. As can be seen they can vary considerably depending on the type of units (for example a low-rate non-submerged trickling filter can achieve a BOD removal efficiency of $80-90$ percent while the range for a high-rate system is 6590 percent); the retention time is also an important factor for certain units, such as sedimentation tanks (Crites and Tchobanoglous, 1998).

Table 2: Typical removal rates for ETP components

\begin{tabular}{lll}
\hline Component & Constituent & $\%$ Removal rate Fine \\
\hline Fine screens & BOD & $5-55$ \\
& TSS & $5-55$ \\
\hline Primary sedimentation tanks & BOD & $25-40$ \\
& TSS & $50-70$ \\
& & Depending on type and detention time \\
\hline Biological: & & \\
Trickling filters & BOD & $50-90$ \\
Activated sludge & BOD and TSS & Final effluent quality $10 \mathrm{mg} / \mathrm{l}$ \\
\hline Anaerobic & COD & $65-95$ \\
\hline
\end{tabular}

Note: removal rate depends on the type of system within each category of which there are many.

A typical ETP consists of an entrance-screening unit followed by an equalization tank and the physicochemical unit, which is usually a combination of neutralization, coagulation, flocculation and clarifier (primary clarifier) unit. One or more biological treatment units along with a clarifier are used after the physicochemical treatment units. The number depends on: the 
Chemical Engineering Research Bulletin 13(2009) 61-66 / Khan et al. quality of the influent; the performance of previous units; the type of the biological unit; and the efficiency of a single biological unit. Finally, wastewater from the biological unit is treated with filters (generally sand or activated carbon filters) depending on the wastewater quality. Overall an ETP comprised of an appropriate combination of physicochemical and biological treatment units can remove upwards of 90 percent of BOD and COD (Ali etal, 2005).

In addition to BOD, COD and TSS, parameters of importance are color, odor, total dissolved solids (TDS), turbidity, conductivity, dissolved oxygen (DO), $\mathrm{pH}$, alkalinity, hardness, metals and ions. For biological treatment, microorganisms may be monitored along with sludge volume index (SVI) and stirred sludge volume index (SSVI).

In this study only the parameters considered to be of most importance or which give an indication of overall pollution load (e.g. BOD and COD) were measured.

It is reflected the type of waste, the national standards, and the facilities and funds that a factory would have available to them for monitoring. Since this method was intended to be regularly repeated it could not be overly expensive. The units that would be sampled in standard monitoring program of a typical ETP are summarized in Table 3 along with the parameters that would be analyzed for monitoring just a few simple parameters may facilitate the assessment of the performance of the whole plant if done in an effective and systematic way (Khan etal, 2006).

It is mentionable here that due to the nature of the dyeing process, which can take between six and twelve hours, the effluent reaching the treatment plant can vary throughout the day. The samples collected were, therefore, a composite of several dying batches which had been combined in the equalization tank. The assumption is that the equalization tank is of sufficient capacity and well mixed enough to ensure the effluent passing through the system is of consistent quality $[8,9]$. It is also assumed that the dyeing operations taking place do not significantly enough for this to effect quality over the period being studied. These are large assumptions, but it is normal for such assumptions to be made in routine monitoring of an ETP and is also a pragmatic approach when effluent treatment is an additional activity to the core business of the industry, and one that rarely results in increased profit.

\section{About the Mozart Knitting Ltd.}

The industrial unit in which the research conducted undertakes knitting, dyeing and sewing of cotton (usually referred to as a composite industry); it has a daily production capacity as shown bellow.

A. Sewing capacity / output: Item wise

\begin{tabular}{lr} 
Product & Annual output (pc) \\
\hline T-Shirt & $22,46,000$ \\
Polo Shirt & $8,73,000$ \\
Sweat Shirt & $9,54,000$ \\
Trouser & $4,77,000$ \\
Spaghetti / Ladies tops & $31,20,000$ \\
Jacket & $4,77,000$ \\
Panty / Brief & $9,36,000$ \\
\hline
\end{tabular}


B. Dyeing \& finishing capacity:

C. Knitting capacity (grey

Machine Type

Single Jersey

Engineering stripe (Mechanical)

Engineering Stripe (Electronic)

Rib

Rib, Interlock with quick change

3 yarn fleece
$12,000 \mathrm{~kg} /$ day

$7,380 \mathrm{~kg} /$ day

Total output / day

$1160 \mathrm{~kg}$

$1600 \mathrm{~kg}$

$300 \mathrm{~kg}$

$960 \mathrm{~kg}$

$1040 \mathrm{~kg}$

$2320 \mathrm{~kg}$

$7380 \mathrm{~kg} /$ day

D. Raw Materials: Knit fabric of following the structure with the cotton, blended cotton like PC, CVC, Polyester, Micro polyester, Viscose, Polyamide etc. manmade fibers with 5,10 or $20 \%$ elastomeric yarn (commonly called Lycra yarn) as per the requirement of the Buyers.

1) Single Jersey fabric: Finer quality single Jersey fabrics ranging from 90 GSM upto 320 GSM fabric weight by our 20 GG, 24GG, 28 gage \& 32 Gage machine. Feeder Stripe repeat width $=7.5 \mathrm{~cm}$. Pique $/$ Locust $=100$ GSM -400 GSM French Terry $/ 2$ yarn fleece $=140$ GSM -250 GSM

2) Interlock Fabric: The project has design cam set to do various interlock structure. Range $=160$ GSM -240 GSM

3) Rib Fabric: $1 \times 1$, $2 \times 2$ etc various rib structure: Range $=130$ GSM to 280 GSM

4) Three thread Fleece : Brushed / Uncrushed = 160 GSM - 300 GSM

5) Engineering stripe (four color): Single Jersey, Pique, Locust etc all structure, stripe width = Unlimited. 120 GSM to 200 GSM fabric weight.

All Circular Knitting machine are equipped with digital stitch length measuring device with

E. Sources of water: Deep Tube well.

F. Boiler Capacity: Two boilers (6 tons each).

G. Disposal Method of Treatment: Effluent Treatment Plant.

H. PRODUCTION PROCESS AND EFFLUENT GENERATION:

1. Number and Capacity of Process Machines:

a) Knitting Section: Knitting section is equipped with pick counter to measure stitch length; Wrap Reel and Yarn examining machine to monitor the yarn count \& yarn quality. There are total 23 no. of machines of various types.

b) Dyeing Section: The dyeing section is equipped with high-temp dyeing machines with all automatic options with central control program

\begin{tabular}{|l|c|c|}
\hline \multicolumn{1}{|c|}{ Machine } & No of Machine & Total loading capacity \\
\hline Fong's (HT HP) & 1 & $60 \mathrm{~kg}$ \\
\hline Fong's (HT HP) & 1 & $240 \mathrm{~kg}$ \\
\hline Fong's (HT HP) & 2 & $800 \mathrm{~kg}$ \\
\hline Fong's (HT HP) & 2 & $1600 \mathrm{~kg}$ \\
\hline Fong's (HT HP) & 1 & $1200 \mathrm{~kg}$ \\
\hline
\end{tabular}


c) Garments Section:

1) Special sewing machines like zigzag, picot ting, Fagot ting, Shell stitch, decorative stitch, feed of the arm, elastic attaching machine, 4 needle- 6 thread machines, Auto fabric trimmers, Knot tying mechanism etc to ensure good sewing finish and decoration to the fashionable items to meet the buyer's requirement.

2) Conveyor type needle detecting machines (YDS, U.K.) to check any broken needle in the garments especially in the kid's items.

3) Fusing machines to make the collar of polo-shirt

4) Sample room is equipped with dedicated sewing machines for making sample by multi skilled sample makers \& pattern makers.

5) A total of 525 sewing machines have been installed within 17 lines cater the need of the buyers in the summer as well as the winter programs.

2. Final Production kg/day: Dyeing-12,000 kg / Day

\section{Utilization of ETP at Mozart Knitting Ltd.:}

According to provided factory profile:

- This is a Biological Effluent Treatment Plant.

- Iron removal plant and hardness removal plant to ensure appropriate quality of water and to ensure correct shade especially in white color and critical colors.

- Two gas generator (1431 KVA \& $1287 \mathrm{KVA}$ ) to meet the demand of the total electricity of the factory.

- Standby Diesel generator (650 KVA) to meet the emergency electricity demand in case of failure of the gas supply.

- Standby Air Compressor to prevent any interruption of compressed air supply to keep the machines running and to ensure uninterrupted production.

- Second standby Deep Tube well to prevent any interruption of water supply to the dyeing section.

- Two boilers (6 ton each) to make the operation more flexible and optimize the gas consumption. High pressure gas line (150 psi) to ensure gas supply even at acute gas shortage.

\section{J. GREen insides of THE PROJeCt:}

The project has several Green Features. Some of them are depicted below:

\section{Effluent Treatment Plant:}

The most important green feature of the project is Effluent Treatment Plant (ETP). The project has a hybrid (chemical \& biological) ETP which was built in 2010. Total construction cost of the project is about Tk. 30.00 million which include civil cost and electrical and mechanical equipment costs. Daily expenditure of the plant are as follows:
a) Chemical Cost/day: About Tk. 25,000.00.
b) Average Power Consumption/day: 1,200 unit of electricity.
c) Man power occupied: 6 persons.
d) Process Flow Chart of the Plant 


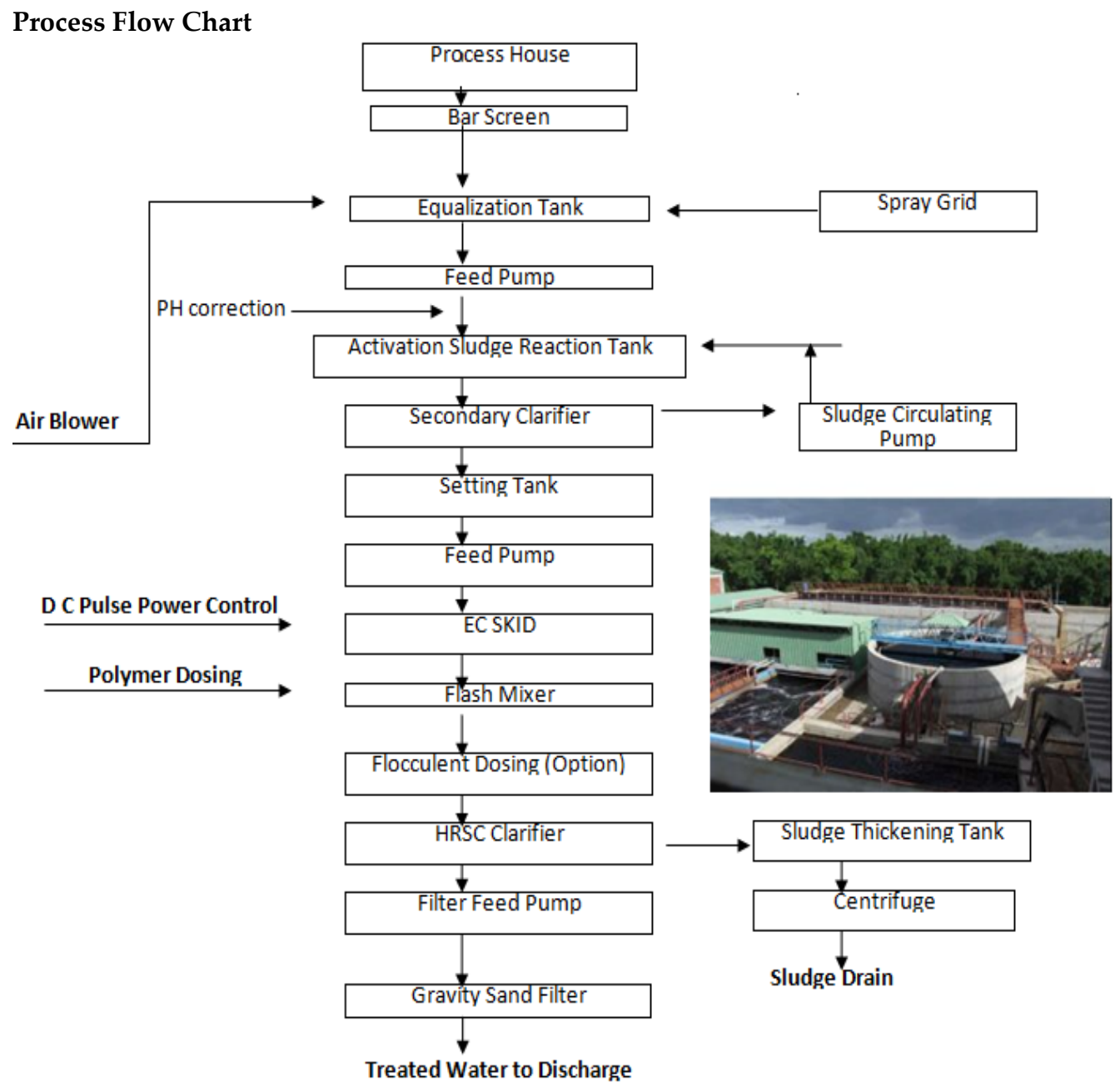

Analysis Sheet of Waste Water Sample of Mozart Knit 1td., by Department of Environment, Dhaka Laboratory:

\begin{tabular}{|l|c|c|c|c|c|c|c|}
\hline Sample Location & Date & Lab code no. & $\mathbf{p H}$ & DO mg/L & BOD mg/L & COD mg/L & TDS mg/L \\
\hline Inlet of ETP & $24 / 01 / 13$ & H-74 & 7.26 & 0.0 & 140 & 369 & 1442 \\
\hline Outlet of ETP & $24 / 01 / 13$ & H-58 & 8.10 & 4.7 & 32 & 200 & 1495 \\
\hline $\begin{array}{l}\text { Bangladesh Standard for Waste Water from } \\
\text { industrial Units, discharge to inland surface } \\
\text { water as per ECR 1997 }\end{array}$ & $6.0-9.0$ & $4.5-8.0$ & $\leq 50$ & $\leq 200.0$ & $\leq 2100.0^{\prime}$ \\
\hline
\end{tabular}

\section{Note: $\mathrm{BOD}$, temperature at $20^{\circ} \mathrm{C}$}

The Department of Environment showed on February 10, 2013 that in result of purified liquid: DO parameter is under acceptable measurement as per ECR 1997.

2. Laboratory Facilities: The Company has structured Laboratory facilities. Details are as below:

a) A Laboratory complete in all respect to enable to conduct test to ensure quality of yarn, fabric and garments; chemicals and water for dyeing as per international standard. 
b) The lab is equipped with Spectrophotometer, Greta Macbeth, Color Eye 7000A from USA.

c) The lab dyeing machines are High temperature, programmable, infra red heating system from DAELIM, Korea.

d) The colour cabinet, wrap reel, pick counter, crock meter, washing colour fastness, light fastness, yarn examining, pilling tester, lab washing machine to test shrinkage with tumble dryer etc from SDL, UK.

e) Sample dyeing woven, brand-Forlab, from Turkey.

3. Quality assurance:

a) Grey fabric inspection simultaneously both the sides with length measuring unit and PC based defect date logging and Analyzing Software System.

b) In process quality control at each level of production like grey inspection, fabric inspection, in line sewing inspection, line end inspection (100\% inspection), after iron inspection, get up inspection after final inspection by a competent team as per buyer recommended A.Q.L.

c) Other facility

\section{Gas Singing Machine:}

The Company has quality Tubular Gas Singing Machine from Dornier, Germany. Hairs on the surface of fabric is burned precisely and as such the fabric surface is very smooth and no pilling, even in interlock fabric.

\section{Raising machine:}

The Company has raising machine from Lifer and fabric surface can be brushed as per buyers' desire to give a velvet touch on pique, interlock, 3 yarn/ 2 yarn fleece etc fabric.

\section{Compliance \& Certifications.}

In spite of the above wanting, the company has passed WRAP certification \& ISO9001:2008. WRAP number is: \# 12665. Because of very few factories in Bangladesh are complied international standard. They are Dollar General of USA and PVH approved. They passed CTPAT. NIKE has also conducted Audit in their factory and they are under CAP. Their customers are also auditing the factory time to time as per their requirement. They have obtained the following certificates.

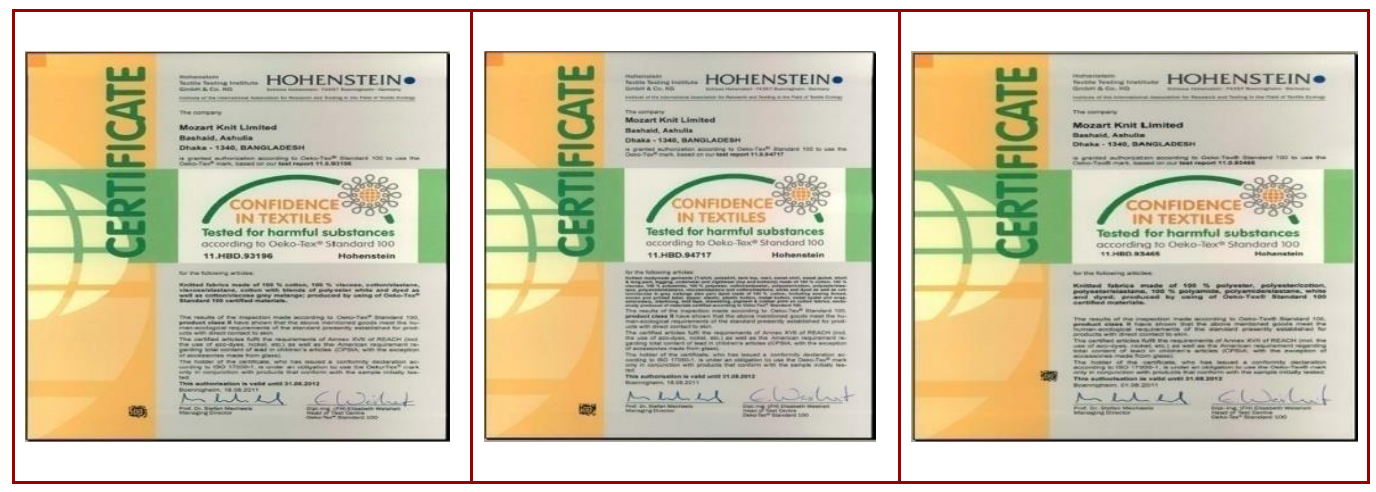






\section{K. Some insight Observation:}

- The company has installed Natural Water Cooling System for every factory floor which is environment-friendly and very much congenial to work for the worker. The cooling system makes cool the atmosphere of the floors, but there is no emission of any Green House Gas. There are medical center, canteen, hostel and day care center in the premise which denotes labor friendly environment.

- There is a system of Time card punching machine for monitoring timely "IN \& OUT" of the workers and thereby ensure worker attendance, overtime, as well as timely calculation of salary with a maximum accuracy which save papers and other stationery.

- The company has installed a Software to introduce computer-aided system of production planning, HRD, commercial, purchase, Accounts and inventory control.

- There is a classroom/ Training center for workers with Latest Teaching Aids and Equipment.

- There is a well system of protection against fire. The company has public address system.

- There is a Central Ware House for efficient material handling. The company ensures minimum wastage at each level of production.

- The factory infrastructure is good which designed by renowned architects. Proper layout of machinery in the production floors by experienced personnel's considering work agronomy to bring maximum efficiency of the workers.

- The company has an informative and formative website.

- They dispose the metal like broken needle to the renewable industry.

- $\quad$ The company complies with both technical and social compliance.

\section{Observation of ETP:}

The overall performance of the ETP is inadequate to meet the national discharge quality standards and, therefore, requires immediate interventions to address the problems. Many of these may be management focused rather than structural and should, therefore, not require any significant financial outlay by the factory, in fact, better management of the plant could reduce costs.

The waste discharge quality standards differ according to the point of disposal. So, the standards are different for inland surface water (ponds, tanks, water bodies, water holes, canals, river, springs or estuaries); public sewers (any sewer connected with fully combined processing plant including primary and secondary treatment); and irrigated land defined as an appropriately irrigated plantation area of specified crops based on quantity and quality of wastewater. 
A major issue that needs to be addressed in the equalization tank is the $\mathrm{pH}$. The dosing of an acid (usually hydrochloric acid) would lower the $\mathrm{pH}$ and thus bring it to within the limits required for biological activity which would help to ensure a healthy population of bacteria in the two biological treatment units. It would result in an overall improvement in the treatment, particularly in the reduction of organic matter, measured as BOD which needs to be reduced further in order to meet the national standards. The TSS values of the influent were below the national standard and remained low during the treatment process. It is unsurprising as the effluent from textile dyeing processes has low TSS.

Total dissolved solids are a particular problem for textile dyeing industries because a large quantity of salts is required in the process, all of which is disposed of with the final effluent. The TDS values in the sample factory showed considerable variation throughout the treatment process. This may be a result of different influxes of chemicals discharged over the course of the dyeing process and the factory should check this more regularly so that they better understand their waste and can manage the treatment better.

It would however be expected that the equalization tank would lessen the variation, which suggests that the equalization tank may not be of sufficient capacity or have a long enough retention time. The TDS values also increased at some stages of the treatment process. These increases appear to be associated with chemical dosing to the treatment plant (in this case possibly nutrients in the biological treatment unit) which implies that the ETP operator is adding excessive quantities of chemicals. It may also relate to the dosing of incompatible chemicals and the underperformance of the biological reactor, which in turn is in part due to the poor control of $\mathrm{pH}$. The results showed that poor management, especially chemical dosing, was seriously affecting the ETP's performance and that simple measures could address the problems. Some sort of equipments such as middle pathway, water transferring pipes has to be repaired immediately.

\section{BANGLADESH BANK INITIATIVES}

BB has proactively come forward to complement by putting in place a fund of taka 2.0 billion to refinance lending for renewable energy generation and other environmentally beneficial projects like ETPs, energy efficient kilns for brick fields and so forth.

As of December 2012, taka 853.54 million out of taka 2.0 billion revolving fund allocated by $\mathrm{BB}$ to the following green categories:

\begin{tabular}{ll}
\hline Category & Amount (Taka in million) \\
\hline Solar irrigation pump & 23.90 \\
Solar home system & 102.84 \\
Biogas plant & 262.70 \\
Effluent Treatment Plant (ETP) & 90.40 \\
Hybrid Hoffman Kiln (HHK) & 124.80 \\
Solar PV module assembling plant & 248.80 \\
\hline Total & $\mathbf{8 5 3 . 5 4}$ \\
\hline
\end{tabular}



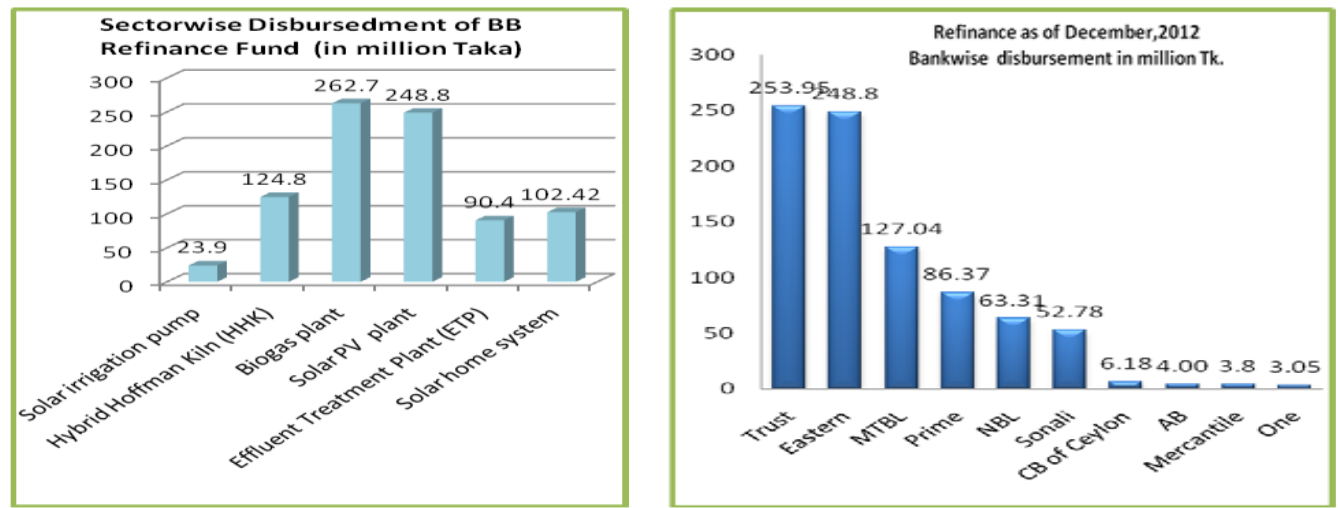

Around taka 853.54 million has been disbursed under Refinance Line of BB of which 43.99\% 30.8\%, 14.62\% and 10.59\% was disbursed for Solar Energy, Biogas, Hybrid Hoffman Kiln and Effluent Treatment Plant respectively (Annual Report, BB; 2012 ).

\section{Commercial Banks Green Finance}

Private Commercial Banks (PCBs) have maximum contribution Out of taka 270921.53 million (66\%) whereas State Owned Commercial Banks (SCBs) and Specialized Development Banks have only $2 \%$ and $3 \%$ respectively.

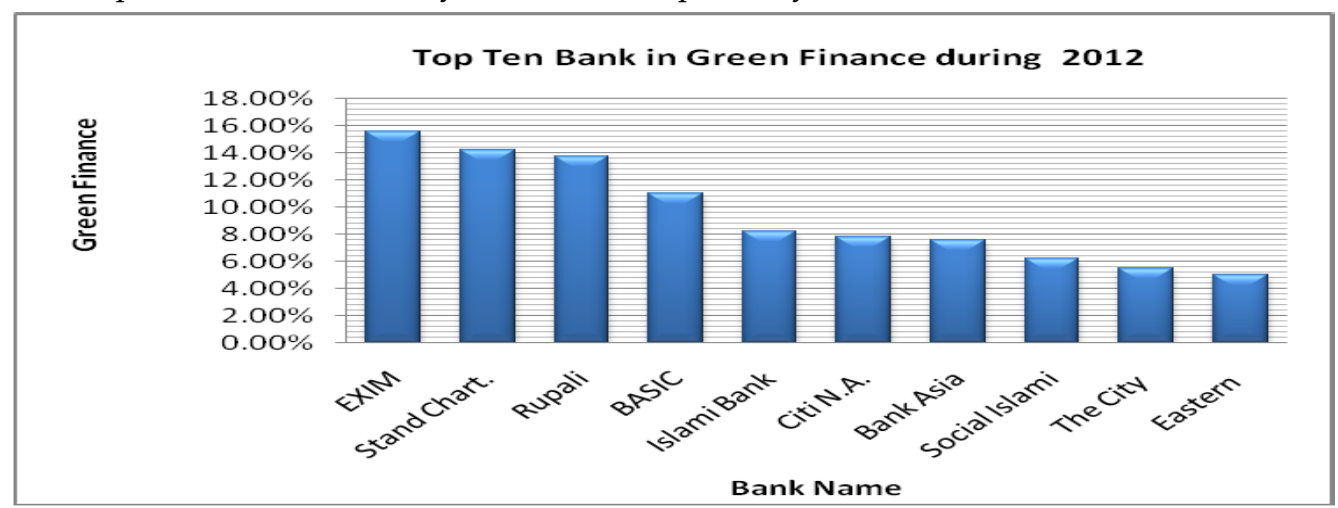

Top ten banks are contributing to a great extent having $90 \%$ share of the total Green Finance.

Exim Bank Ltd., is on the top among them with more than 15\% share. Banks have disbursed in different green products/events as taka 1356.52 million in ETP, taka 259100.05 million in project having ETP, taka 899.87 million in Bio-gas plant, taka 3638.37 million in solar/ renewable energy and taka 1830.33 million in HHK etc. during 2012 (Annual Report, BB; 2012 ).

\begin{tabular}{llllll}
\hline Green Projects/Events & SCBs & PCBs & FCBs & SDBs & Total (MillionTaka) \\
\hline ETP & 118.81 & 687.89 & 162.8 & 387.02 & 1356.52 \\
Projects having ETP & 2994.15 & 173187.17 & 76517.03 & 6401.70 & 259100.05 \\
Bio-gas Plant & 9.73 & 283.82 & 0 & 606.32 & 899.87 \\
Solar/Renewable Energy Plant & 984.94 & 1685.56 & 718.48 & 249.39 & 3638.37 \\
Bio-fertilizer Plant, & 0.00 & 0.40 & 0 & 0 & 0.40 \\
Hybrid Hoffman Kiln (HHK) & 538.71 & 841.96 & 0 & 449.66 & 1830.33 \\
Others & 1860.91 & 2089.58 & 0 & 110.97 & 4061.76 \\
Reduced Rate of Interest & 0.00 & 34.26 & 0 & 0 & 34.26 \\
\hline
\end{tabular}




\section{RePERCUSSION FOR AdOPTING THIS UNIT \& Other UNITS}

The monitoring program used in this industrial unit was simple and quick, yet it clearly highlighted some significant problems with the management of the system that were having a detrimental impact on its efficiency. As expected it aided the identification and diagnosis of problems within certain units. It is of far greater benefit to the ETP manager than the knowledge that the ETP is not meeting national standards. It is essential that the $\mathrm{pH}$ in the biological units is maintained between $\mathrm{pH} 4$ and 9.5 and ideally between 6.5 and 7.5 if the bacteria are to remain alive and active and thus treat the waste. It is reasonably simple to achieve if an automatic monitoring and dosing system is installed. Monitoring and dosing can be done manually, but it is far more efficient and practical to install such a system because the $\mathrm{pH}$ can fluctuate significantly throughout the day, depending on the processes in the factory. The dosing of other chemicals must also be correct otherwise the TSS and TDS may not be reduced, and may even increase. Managers of ETPs should regularly monitor the units in the plant where chemical dosing takes place so that they know their waste and can be more accurate in their dosing of chemicals. It is also good practice to perform laboratory jar tests on different types of waste from the factory for the same reason.

Although the BOD5 and COD reduced through the system, the concentrations were still above the national standards in the final effluent. This means that there is scope for improvement through better operation of the plant. It may be necessary to ensure that the biological reactors are adequately aerated and that the correct nutrient composition is being added to "feed" the bacteria, as textile effluent contains very little of the nutrients, including nitrogen and phosphorus, required for a healthy and active bacterial population. Maintaining the purity of the chemical nutrients used is also very important in order to avoid an increase in TDS. Factory treatment plants could potentially be modified to receive urine from the toilets (or the liquid portion of septic tanks), which would provide the nutrients without the needs for chemical dosing (although further steps may be required for pathogen removal if the urine is not separated from the faces at source).

The project has many green insights, but there are scopes to make it more environments friendly. Following are some areas where there are scopes for developments which the project may adopt to make it more environment friendly:

- Paper work may be decreased by using automation in the administrative work.

- Water may be recycled to household use.

- Website may be more informative.

- There is no renewable energy use in the premise. The company should use renewable energy.

- There is not seen any scope to use the daylight. The company should take initiative to use daylight to save energy.

- The project may introduce eco friendly dyeing system in the process, like resizing with biocatalyst rather acidic or oxidative. Resizing with biocatalyst involve:

$\checkmark$ Less chemical involved.

$\checkmark$ Eco friendly.

$\checkmark$ Efficient in wide range temperature.

$\checkmark$ Better strength retention.

$\checkmark$ Softer Fabric feels etc. 


\section{Conclusions}

In Bangladesh and other countries in the region effluent treatment from textile dyeing factories and other industrial processes is usually required by law and often expected by international buyers. Despite the issue of significant compliance, the treatment is regularly below standards and is rarely checked either by the factory, environment departments or buyers. There are a several reasons for this, but the bottom line is usually due to lack of funds and technical expertise. These reasons are also why factories found running their ETPs sub-optimally. This study shows that through the process of simple monitoring of key parameters at strategic places in the treatment plant, the ETP manager would be able to optimize the treatment process and potentially save money by reducing the chemicals and energy needed to run the system.

The main problems experienced by factories with ETPs are inadequate treatment due to incorrect dosing of chemicals required in the treatment process or inactivity and even death of necessary micro-organisms, due to the $\mathrm{pH}$, insufficient oxygen or lack of nutrients.

All of these can be addressed through better management; usually chemical dosing. By regularly monitoring and understanding their wastewater properly, ETP managers can make effective decisions to achieve optimal ETP functioning.

Furthermore, factories supplying international buyers can use this data to demonstrate their 'green' credentials and thus generate more business or at the very least maintain their share in an increasingly competitive market.

\section{ACRONYMS}

$\begin{array}{ll}\text { BOD } & \text { Biological Oxygen Demand } \\ \text { COD } & \text { Chemical Oxygen Demand } \\ \text { DO } & \text { Dissolved Oxygen } \\ \text { DOE } & \text { Department of Environment } \\ \text { ECA } & \text { Environment Conservation Act, 1995 } \\ \text { ECC } & \text { Environmental Clearance Certificate } \\ \text { ECR } & \text { Environmental Conservation Rules, } 1997 \\ \text { ETP } & \text { Effluent Treatment Plant } \\ \text { TDS } & \text { Total Dissolved Solids } \\ \text { HTHP } & \text { High Temperature High Pressure }\end{array}$

\section{REFERENCES}

Ali M, Ahmed S and Khan M, Characteristics and Treatment Process of Wastewater in a Nylon Fabric Dyeing Plant, Journal of Chemical Engineering, The Institute of Engineers, Bangladesh, 2005. ChE23 (1):pp. 17-22

Annual Report on Green Banking 2012 by Bangladesh Bank.

BGMEA \& BKMEA Homepage: http://bgmea.com.bd, Cited: 20 June 2013

Chemical Engineering Research Bulletin 3 (2009) 61-66 [Khan et al]

Choosing an Effluent Treatment Plant by Stockholm Environment Institute collaboration with Bangladesh Centre for Advanced Studies and the University of Leeds.

Crites R and Tchobanoglous G, Small and Decentralized Wastewater Management Systems, McGraw-Hill, New York, 1998 
Khan M, Knapp J, Clemett A, Chadwick M and Mahmood M, Managing and Monitoring Effluent Treatment Plant, Managing Industrial Pollution from Small and Medium Scale Industries in Bangladesh Booklet Series, SEI, BCAS, University of Leeds, Dhaka, Bangladesh, 2006

Lash D and Kominek E, Industrial Wastewater and Solid Waste Engineering, Ch. Primary-WasteTreatment Methods, McGraw-Hill, New York, 1980. pp. 81-123

Noyes R, Unit Operation in Environmental Engineering, Noyes Publications, New Jersey, USA, 1994

Sharif MI and Hannan MA, Guide to the Environmental Conservation Act 1995 and Rules 1997, Bangladesh Centre for Advanced Studies (BCAS), Dhaka, Bangladesh, 1999

Tchobanoglous G, Burton FL and Stensel HD, Wastewater Engineering: Treatment and Reuse, McGraw-Hill, New York, 4th edition, 2003

$>$ http://wiki.answers.com/Q/How_do_effluent_treatment_plants_and_water_treatment_plants_work

$>$ http://www.mozartknitltd.com

$>$ mpcb.gov.in/images/pdf/part.pd

$>$ www.doe-bd.org/ETP_Assessment_Guide.pdf

$>$ www.mrsc.org/policyprocedures/a5wwtpsafetymanual.pd

Interview and information provided by Pablo (Pabs) G. Gonzales, General Manager, Mozart Knit Limited and Engr. Md. Shahin Howlader 